\title{
Physiological and Physicochemical Responses of 'Sai Nam Phueng' Tangerine to Commercial Coatings
}

\author{
Pimjai Seehanam ${ }^{1}$ and Danai Boonyakiat \\ Department of Plant Science and Natural Resource, Faculty of Agriculture, \\ Chiang Mai University, Chiang Mai 50200, Thailand
}

\author{
Nithiya Rattanapanone \\ Department of Food Science and Technology, Faculty of Agro-Industry, \\ Chiang Mai University, Chiang Mai 50200, Thailand
}

Additional index words. tangerine, coatings, quality, ethanol, internal gases

\begin{abstract}
Tangerine fruit cv. Sai Nam Phueng was coated with six commercial coatings: Citrashine, Fomesa, Citrosol AK, Supershine-C, Zivdar, and Perfect Shine. Fruit were coated using gloved hands and stored at room temperature $\left(23 \pm 3{ }^{\circ} \mathrm{C}\right)$ and $56 \% \pm 5 \%$ relative humidity. Physiological and chemical properties were recorded on Days $0,1,4,7$, 10, and 13. All coated fruit had lower respiration rates, reduced weight loss, higher gloss, and better appearance than control fruit. Coatings somewhat increased total soluble solids levels, but had no major effects on $\mathrm{pH}$, titratable acidity, or vitamin $\mathrm{C}$ contents. Among the various wax formulations, tangerines coated with Zivdar, and to a lesser extent Perfect Shine, had the highest internal $\mathrm{O}_{2}$ and lowest internal $\mathrm{CO}_{2}$ levels, resulting in the lowest juice ethanol levels. Application of other coatings, especially Citrosol AK and Supershine-C, resulted in enhanced accumulation of off-flavors and decreased sensory acceptability.
\end{abstract}

Tangerine (Citrus reticulata Blanco) is a subtropical fruit of high commercial value in the fruit market and is commonly consumed as a fresh fruit in Thailand. In commercial practice, tangerine fruit are coated to increase shine and reduce water loss. Many imported coatings are being used by various packinghouses in Thailand. Surface coatings can improve the postharvest quality of horticultural commodities (Hagenmaier and Baker, 1995). A principal disadvantage of coatings is the development of off-flavor, which can be adversely affected by the coating for reasons related to permeation of gases through the peel (Hagenmaier, 2002; Hagenmaier and Baker, 1993). If anaerobic conditions occur, an excessive build-up of volatile compounds such as acetaldehyde and ethanol in citrus fruit can lead to the production of off-flavor (Chen and Nussinovitch, 2000, 2001; Shaw et al., 1991). Coated mandarin fruit are very susceptible to anaerobic respiration (Cohen et al., 1990).

\footnotetext{
Received for publication 14 Sept. 2009. Accepted for publication $19 \mathrm{Jan} .2010$.

We thank the Office of the Higher Education Commission, Thailand, for supporting the grant fund under the program Strategic Scholarships for Frontier Research Network for the Ph.D. Program Thai Doctoral degree for this research and also thank the Thailand Research Fund and Faculty of Agriculture, Chiang Mai University, for their support. We especially thank Robert D. Hagenmaier and Elizabeth A. Baldwin (USDA Citrus \& Subtropical Products Laboratory, Winter Haven, FL) for advice on the manuscript.

${ }^{1}$ To whom reprint requests should be addressed; e-mail pimjail93@hotmail.com.
}

Coatings can be formulated from lipids, resins, polysaccharides, proteins, and synthetic polymers (McHung, 1996). They can create different levels of water loss and modify internal atmosphere depending on the chemical nature, thickness, and character of the surface cover (Amarante et al., 2001; Hagenmaier and Baker, 1993). There is little information on how the citrus coatings that are currently being used in Thailand affect quality of the local fruit. In the present study, we compared six commercial coatings on physiological and physicochemical changes of tangerine fruit cv. Sai Nam Phueng. The responses to the coatings are expressed in terms of internal gas concentration, ethanol content, off-flavor development, respiration rate, and chemical compositions of tangerine fruit during storage.

\section{Materials and Methods}

Plant material. Tangerine fruit cv. Sai Nam Phueng was harvested at commercial maturity from a commercial orchard in Fang district, Chiang Mai province, Thailand, in Dec. 2006. Fruit were transported to the Postharvest Horticultural Laboratory, Department of Plant Science and Natural Resource, Faculty of Agriculture, Chiang Mai University. Fruit were selected for weight range $\approx 90$ to $130 \mathrm{~g}$ and defect-free.

Postharvest treatments. Tangerine fruit were cleaned with a dried cotton cloth and coated with six different commercial coatings, which are usually used by packing houses (Table 1) and non-coated fruit were used as controls. Coatings were applied man- ually using an average $0.2 \mathrm{~g}$ of wax/fruit spread evenly over the fruit surface using latex-gloved hands and air-dried at room temperature. The tangerines were stored at room temperature $\left(23 \pm 3{ }^{\circ} \mathrm{C}\right)$ and $56 \% \pm 5 \%$ $\mathrm{RH}$ for $13 \mathrm{~d}$.

Weight loss. Weight loss was determined with samples of 10 fruit per treatment. The fruit from each treatment were weighed on Days $0,1,4,7,10$, and 13 of storage. The weight losses are expressed as the percentages of the Day 0 weight.

Gloss. Reflectance measurements of fruit shine were made in gloss units with the microTRI-gloss reflectance meter (BYK Gardner Inc., Silver Spring, MD) fitted with a shield having a 19-mm diameter hole (Hagenmaier and Baker, 1994). For each experiment, 10 measurements per fruit were made on each of 10 numbered tangerine on Day 1.

Estimation of off-flavor. Ten untrained panelists evaluated off-flavor by tasting using a scale of 1 to 4 in which $4=$ excellent, $3=$ slightly off-flavor, 2 = moderately off-flavor, and $1=$ extremely off-flavor. Fruit taste was rated "unacceptable" when the taste score was below 3 .

Visual appearance. Tangerine fruit were rated for visual quality, wilting, and shriveling using a scale of 1 to 5 in which $5=$ excellent, $4=$ good, $3=$ fair, $2=$ poor, and $1=$ unusable. Fruit appearance was rated "unacceptable" when the score was below 3 .

Determination of internal $\mathrm{O}_{2}$ and $\mathrm{CO}_{2}$. Ten fruit were used per treatment for each coating. The internal gas was withdrawn by a syringe (previously flushed with helium gas to remove oxygen) with the needle inserted through the blossom end into the internal space of fruit submerged in water (Hagenmaier, 2001). The $\mathrm{O}_{2}$ and $\mathrm{CO}_{2}$ concentrations were measured with a gas chromatograph (Model GC-8A; SHIMADZU, Tokyo, Japan) equipped with a thermal conductivity detector fitted with a CTR-1 column $(2 \mathrm{~m} \times 6 \mathrm{~mm}$ o.d.) (Alltech, Deerfield, IL) consisting of an outer column (Parapak Type N; 80-100 Mesh; SHIMADZU). The column temperature was $65^{\circ} \mathrm{C}$ and the thermal conductivity detector was $110{ }^{\circ} \mathrm{C}$. Peak areas obtained from standard gas mixtures were determined before and after analysis of samples. Oxygen concentration was calculated from the $\mathrm{O}_{2}-\mathrm{Ar}$ peak area after correction for $0.9 \% \mathrm{Ar}$ in atmosphere (Hagenmaier, 2001).

Determination of ethanol content. Ethanol in fruit juice was measured using an ethanol assay kit (Diagnostic Chemical Limited, Charlottetown, Canada) as described by Bonnichsen and Theorell (1951). The pooled juice of 10 fruit was extracted using a juice maker. Ten microliters of juice was mixed with $1.5 \mathrm{~mL}$ of buffer-NAD-ADH-buffer mixture and incubated for $20 \mathrm{~min}$ at $25 \pm 2$ ${ }^{\circ} \mathrm{C}$. The absorbance was measured at $340 \mathrm{~nm}$ within $30 \mathrm{~min}$. The concentration of ethanol was calculated from a graph made from standard ethanol content. Ethanol was measured in triplicate determinations.

Respiration rate. Respiration rates were measured every $3 \mathrm{~d}$ and eight fruit $(\approx 1 \mathrm{~kg})$ 
Table 1. Commercial coatings, main components, and their sources.

\begin{tabular}{|c|c|c|c|}
\hline Name of commercial coating & Abbreviation & Main components ${ }^{\mathrm{z}}$ & Source of product \\
\hline Citrashine & CIS & $\begin{array}{l}\text { Shellac-based wax formulated with purified } \\
\text { natural secretion and water-emulsifying agents }\end{array}$ & Citrashine (Pty) Ltd., South Africa \\
\hline Fomesa (Waterwax) & FOM & $\begin{array}{l}10 \% \text { oxidized polyethylene wax } \\
8 \% \text { glycerol ester of wood rosin } \\
2 \% \text { ammonium hydroxide }\end{array}$ & Fomesa Fruitech, S.L., Spain \\
\hline Citrosol AK & CSA & $18 \% \mathrm{w} / \mathrm{v}$ carnauba and rosin & Productos Citrosol, S.A., Spain \\
\hline Supershine-C & SUS & $\begin{array}{l}18 \% \mathrm{w} / \mathrm{v} \text { waxes, modified gum, rosin, } \\
\text { oxidized polyethylene, and adjuvants }\end{array}$ & Tecnidex, Spain \\
\hline Zivdar & ZIV & $\begin{array}{l}18 \% \mathrm{w} / \mathrm{v} \text { waxes, shellac, polyethylene wax, } \\
\text { and imazalil }\end{array}$ & Safepack Products Ltd., Israel \\
\hline Perfect Shine & PFS & $\begin{array}{l}\text { Carnauba wax, natural resin, fatty acid, } \\
\text { fatty alcohol, ammonia }\end{array}$ & P.S. Wax Tech, Co. Ltd., Thailand \\
\hline
\end{tabular}

${ }^{\mathrm{z}}$ Components were declared on the product labels.

were sealed in a plastic chamber $(17.5 \mathrm{~cm} \times$ $27.0 \mathrm{~cm} \times 11.5 \mathrm{~cm}$ ) with continuous air flow at $23 \pm 3{ }^{\circ} \mathrm{C}$. A $1-\mathrm{mL}$ gas sample was withdrawn with a plastic-tight syringe and analyzed for $\mathrm{CO}_{2}$ by gas chromatograph (Model GC-8A; SHIMADZU) fitted with a Parapak Type N (80-100 Mesh; SHIMADZU) consisting of an outer column (CTR-1 column; $2 \mathrm{~m} \times 6 \mathrm{~mm}$ o.d.; Alltech). The column temperature was $65^{\circ} \mathrm{C}$ and the thermal conductivity detector was $110{ }^{\circ} \mathrm{C}$. The respiration rate was expressed as milligrams of $\mathrm{CO}_{2}$ per kilogram of fruit per hour ( $\mathrm{mg} \mathrm{CO} / 2 \mathrm{~kg} / \mathrm{hr}$ ).

Measurement of total soluble solids (TSS), titratable acidity (TA), pH, TSS/TA ratio, and ascorbic acid. Three fruit of three replications per treatment were squeezed with a hand-press juicer. The juice was measured for total soluble solids content with a digital refractometer (Model PR-101; ATAGO, Tokyo, Japan). The $\mathrm{pH}$ of juice was measured by a pH meter (Model CG 842/ 14 pH; SCOTT, Hofheim, Germany). Titratable acidity (TA) was determined by diluting $10 \mathrm{~mL}$ of fruit juice to $100 \mathrm{~mL}$ with distilled water and titrated with $0.1 \mathrm{~N} \mathrm{NaOH}$ to a $\mathrm{pH}$ 8.2. TA was expressed as percent citric acid per $100 \mathrm{~mL}$ fruit juice. The ratios of total soluble solids (TSS) to TA were calculated as the average of the ratios. Ascorbic acid content was determined by the 2,6-dichloroindophenol titrimetric method (Ranganna, 1986). The results were expressed in milligrams of ascorbic acid per $100 \mathrm{~mL}$ fruit juice.

Statistical analysis. One-way analysis of variance was used to determine treatment effects and comparisons were made at $P \leq$ 0.05 using the least significant difference test to separate means (SPSS software; SPSS Inc., Chicago, IL).

\section{Results and Discussion}

Weight loss. The weight loss of commercially coated fruit was significantly less than that of the control fruit. The least weight loss was exhibited by the Fomesa coating followed by Citrashine, Supershine-C, Zivdar, Citrosol AK, and Perfect Shine (Fig. 1). Weight loss is mainly caused by fruit transpiration in which water moves out of the fruit by vapor phase diffusion driven by a gradient of water vapor pressure between inside and outside of the fruit. The reduction

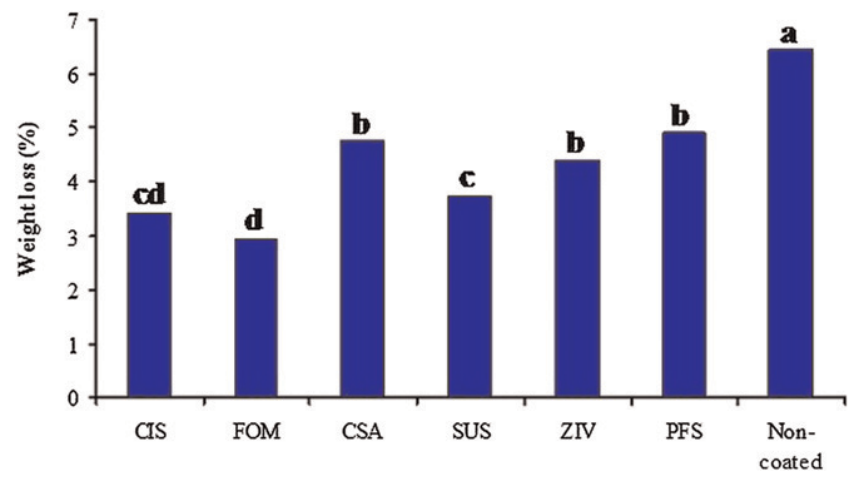

Fig. 1. Effects of commercial coatings on weight loss of tangerine fruit stored at room temperature $(23 \pm$ $3{ }^{\circ} \mathrm{C}$ ) and $56 \% \pm 5 \%$ relative humidity for $7 \mathrm{~d}$. Mean separation between columns by least significant difference test at $P \leq 0.05$.

in weight loss was probably the result of the effects of these coatings as a semipermeable barrier against $\mathrm{O}_{2}, \mathrm{CO}_{2}$, moisture, and solute movement, thereby reducing respiration, water loss, and oxidation rates (Baldwin et al., 1999). The rate of water loss can be reduced by $30 \%$ to $50 \%$ with the use of some waxes (Wills et al., 1998). Carnauba wax and shellac are good barriers of moisture loss, whereas polyethylene have higher permeability of water vapor (Hagenmaier and Baker, 1993; Hagenmaier and Shaw, 1992). Similar results were obtained with Sazuma mandarins and Shamuti oranges. The data show that the lowest weight loss was manifested in Primafresh-coated fruit, whereas the highest weight loss was recorded for the control fruit followed by fruit coated with Britex, PacRiteStorRite, Decco, and Natural Zivdar coatings (Mannheim and Soffer, 1996).

Gloss. Coated 'Sai Nam Phueng' tangerines had higher initial gloss than non-coated fruit (Fig. 2) as previously reported for 'Mor' mandarins (Porat et al., 2005). Tangerines coated with Citrashine and Perfect Shine had the highest gloss unit (Fig. 2). The high-gloss coatings were composed mainly of shellac and wood rosin more than coatings made from waxes such as polyethylene or carnauba wax (Hagenmaier and Baker, 1994). By observation with the naked eye, the gloss of all coatings decreased during storage but remained higher than the uncoated fruit. Decrease of gloss during storage did not depend on coating thickness (Hagenmaier and Baker, 1994).
Estimation of off-flavor. The flavor scores of coated tangerine fruit were evaluated after storage for $7 \mathrm{~d}$. The flavor was perceived as more "fermented" for fruit coated with Supershine-C, Citrosol AK, Citrashine, and Fomesa than for fruit coated with Zivdar and non-coated control fruit (Fig. 3). Flavor can be adversely affected by the coating that reduces permeation of gases through the peel. Citrus fruit, like other plant products in general, continues to respire after harvest, intake $\mathrm{O}_{2}$, and release $\mathrm{CO}_{2}$. Unless these gases are able to pass through the peel without too much restriction, the $\mathrm{CO}_{2}$ concentration builds up in the fruit and the $\mathrm{O}_{2}$ becomes depleted. These changes can result in a change in the respiratory process so that off-flavor is produced (Hagenmaier, 1998). Extremely low $\mathrm{O}_{2}$ levels or excessively high $\mathrm{CO}_{2}$ levels that induce fermentation can result in the generation of off-flavor (Cohen et al., 1990). There was a relationship between the amounts of ethanol content and low $\mathrm{O}_{2}$ and high $\mathrm{CO}_{2}$ concentrations in tangerine fruit. The fruit coatings apparently reduced passage of $\mathrm{O}_{2}$ through the peel and thus created partial anaerobic conditions in the fruit, which resulted in the formation of products of anaerobic respiration, e.g., ethanol and acetaldehyde. The coatings also prevented the exit of $\mathrm{CO}_{2}$, ethanol, and acetaldehyde from the fruit, which led to fermentation and off-flavor induction (Cohen et al., 1990; Mannheim and Soffer, 1996). Baldwin et al. (1995) reported marked increases in flavor volatiles, especially ethanol, 
ethyl butyrate, and ethyl acetate, in 'Valencia' oranges coated with a shellac-based citrus coating and stored at 16 to $21{ }^{\circ} \mathrm{C}$. A high negative correlation between ethanol and flavor has also been reported for mandarin oranges (Ahmad and Khan, 1987) and 'Valencia' oranges (Ke and Kader, 1990).

Visual appearance. Tangerine fruit coated with commercial coatings showed better visual appearance results as compared with the non-coated control fruit. An appearance is the most important quality attribute of fresh produce with primary concern for size and color, uniformity, glossiness, and absence of defects in shape (Aked, 2000). Appearance can be affected by surface dehydration resulting in whitening, waxiness, and discoloration (like resulting from enzymatic browning). Selective coating materials can reduce moisture loss, control surface dehydration and discoloration, delay the surface whitening, and enhance the glossiness of fruit surfaces (Lin and Zhao, 2007). Data regarding storage intervals showed a gradual decline in appearance over the storage period prolonged (data not shown). This may be the result of the loss of moisture, which in turn affected the quality of fruit. Water loss can cause shrinkage, softening of the flesh, ripening, senescence through ethylene production, and other metabolic changes (Bai et al., 2002).

Internal $\mathrm{O}_{2}$ and $\mathrm{CO}_{2}$. Uncoated fruit had lower internal $\mathrm{O}_{2}$, whereas it had $2 \%$ higher $\mathrm{CO}_{2}$ than atmosphere. In contrast, coated fruit had internal $\mathrm{O}_{2}$ lower by $9 \%$ to $16 \%$ and internal $\mathrm{CO}_{2}$ concentrations higher by $3 \%$ to $15 \%$ (Fig. 4). Gas exchange between internal fruit and external atmosphere is by permeation through the cuticle and by diffusion through pores. Application of surface coatings covers the cuticle and may block pores on the fruit surface (Ben-Yehoshua et al., 1985; Hagenmaier, 2000). Coatings with low permeability offer more of a barrier to gas exchange between the fruit and external atmosphere, resulting in a modified internal fruit atmosphere of relatively high $\mathrm{CO}_{2}$ and low $\mathrm{O}_{2}$. This can benefit fruit shelf life in the same way as controlled atmosphere or modified atmosphere packaging does, whereas excessive modification can cause anaerobic metabolism (Hagenmaier, 2002). Furthermore, internal gas composition was highly dependent on coating type and thickness. In previous works, the effects of different types of wax on gas permeability and anaerobic conditions were studied in various orange and mandarin varieties. It was concluded that wax-based coatings, especially for polyethylene-based, are much more permeable than carnauba-, shellac-, and wood rosin-based coatings and are more suitable for coating mandarins (Hagenmaier, 2000; Hagenmaier and Baker, 1993, 1995; Hagenmaier and Shaw, 1992; Mannheim and Soffer, 1996). Hagenmaier and Shaw $(1991,1992)$ measured gas exchanges for many commercial fruit coatings. It was found that resin-based coatings (shellac or wood rosin) were less permeable to $\mathrm{O}_{2}, \mathrm{CO}_{2}$, and ethylene than carnauba and other wax-based coatings. Furthermore,

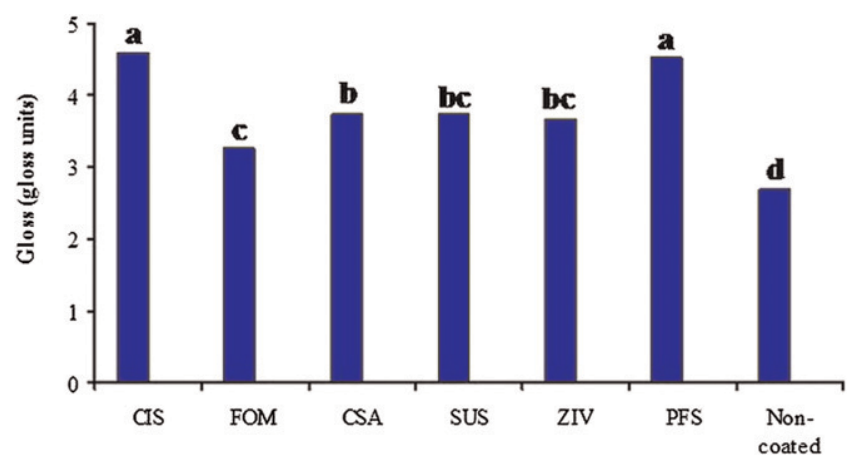

Fig. 2. Effects of commercial coatings on the gloss of tangerine fruit stored at room temperature $\left(23 \pm 3{ }^{\circ} \mathrm{C}\right)$ and $56 \% \pm 5 \%$ relative humidity on Day 1 . The gloss unit was from 0 to 5 , with $0=$ no gloss and $5=$ very glossy. Mean separation between columns by the least significant difference test at $P \leq 0.05$.

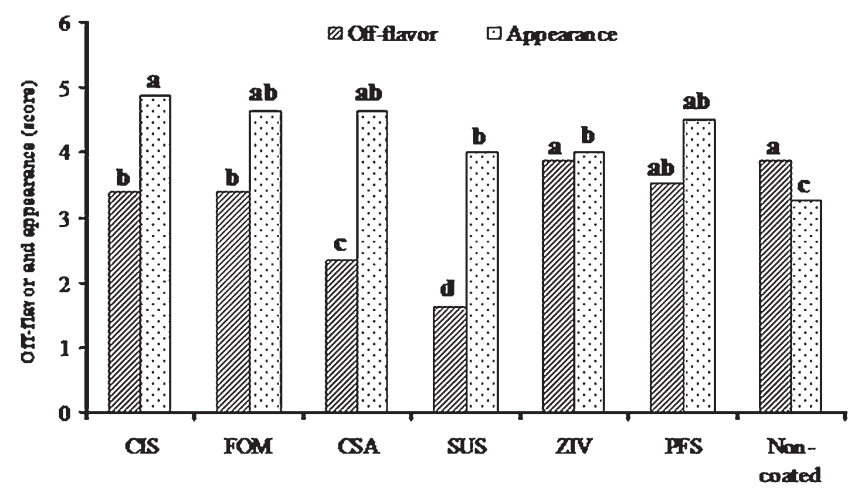

Fig. 3. Effects of commercial coatings on the off-flavor and appearance score of tangerine fruit stored at room temperature $\left(23 \pm 3{ }^{\circ} \mathrm{C}\right)$ and $56 \% \pm 5 \%$ relative humidity for $7 \mathrm{~d}$. The off-flavor score scale was from 1 to 4 , with 1 = extreme off-flavor and 4 = excellent. The appearance score scale was from 1 to 5 , with $1=$ unusable and $5=$ excellent. Mean separation between columns by the least significant difference test at $P \leq 0.05$

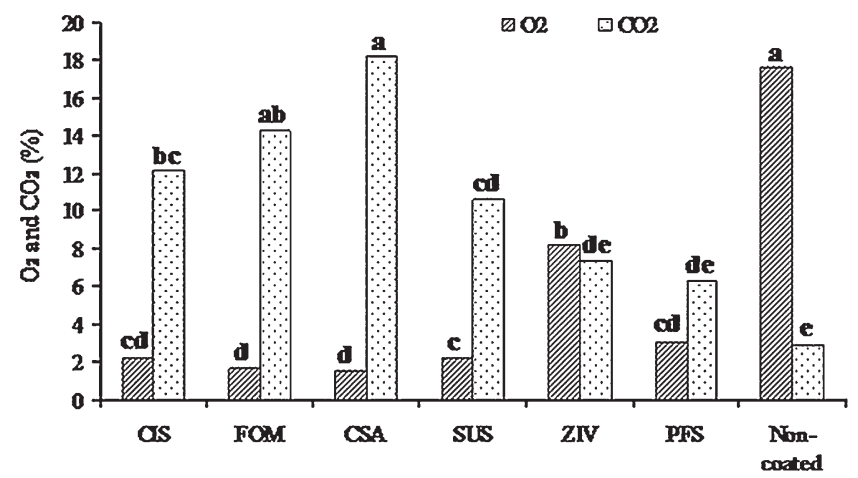

Fig. 4. Effects of commercial coatings on the internal $\mathrm{O}_{2}$ and $\mathrm{CO}_{2}$ of tangerine fruit stored at room temperature $\left(23 \pm 3{ }^{\circ} \mathrm{C}\right)$ and $56 \% \pm 5 \%$ relative humidity for $7 \mathrm{~d}$. Mean separation between columns by the least significant difference test at $P \leq 0.05$.

the internal $\mathrm{CO}_{2}$ of grapefruit and 'Valencia' orange was lower for polyethylene- and carnaubabased coatings than for shellac and resin (Hagenmaier and Baker, 1994).

Determination of ethanol content. Ethanol content of the juice from coated fruit varied considerably for each coating treatment and increased during storage. Non-coated fruit showed the lowest ethanol content. The highest ethanol content occurred in fruit with the Fomesa, Citrosol AK, and Supershine-C coatings. The Perfect Shine and Zivdar coatings gave a relatively lower ethanol content than other coatings (Fig. 5). The coatings that are applied to fruit form barriers to the passage of $\mathrm{O}_{2}$ and $\mathrm{CO}_{2}$ through the fruit peel (Hagenmaier, 2005). Low $\mathrm{O}_{2}$ and/or high $\mathrm{CO}_{2}$ can induce anaerobic respiration and enhance fermentation (Matthesis et al., 1991). Ethanol content in the coating application was notably higher as a result of the amount of rosin (shellac or wood rosin) formulations than that of wax (polyethylene- or carnauba-based) coatings and control fruit. With a lower permeability 
to gases, shellac and wood resin coatings result in lower internal $\mathrm{O}_{2}$, higher internal $\mathrm{CO}_{2}$, and a subsequent build-up of acetaldehyde and ethanol under anaerobic conditions, which leads to off-flavor in citrus fruit (Baldwin et al., 1995; Cohen et al., 1990; Hagenmaier, 2000, 2002; Hagenmaier and Baker, 1993). Ahmad and Khan (1987) found significant amounts of ethanol in waxed mandarins accompanied with a change in flavor. These researchers attributed the off-flavor to an insufficient supply of $\mathrm{O}_{2}$ through the wax coating, which caused partial anaerobic respiration. Similar results were reported for wax-coated 'Pineapple' oranges (NisperosCarriedo et al., 1990).

Respiration rate. Statistical analysis showed a significant difference between control and coated samples for respiration rates.
The control fruit had a higher respiration rate than coated tangerine fruit. Supershine-C coating provided the lowest respiration rate compared with others. The production of $\mathrm{CO}_{2}$ for the coated fruit was lower than in the control (Fig. 6). The suppression of respiration was likely the result of the modification of the internal atmosphere of the fruit (decreasing $\mathrm{O}_{2}$ and increasing $\mathrm{CO}_{2}$ ) caused by the semipermeable characteristics of the coatings to these gases (Banks, 1984). Reduction of the respiration rate as a result of coatings has also been reported for cherries (Martinez-Romero et al., 2006), strawberry (El Ghaouth et al., 1991), and longan (Jiang and $\mathrm{Li}, 2001$ ).

Measurement of total soluble solids (TSS), titratable acidity (TA), pH, TSS/TA ratio, and ascorbic acid. Comparison of

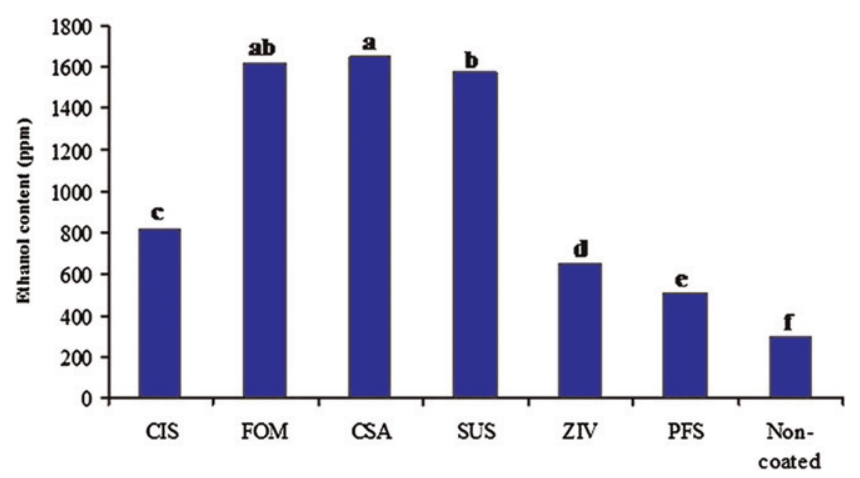

Fig. 5. Effects of commercial coatings on the ethanol content of tangerine fruit stored at room temperature $\left(23 \pm 3{ }^{\circ} \mathrm{C}\right)$ and $56 \% \pm 5 \%$ relative humidity for $7 \mathrm{~d}$. Mean separation between columns by the least significant difference test at $P \leq 0.05$.

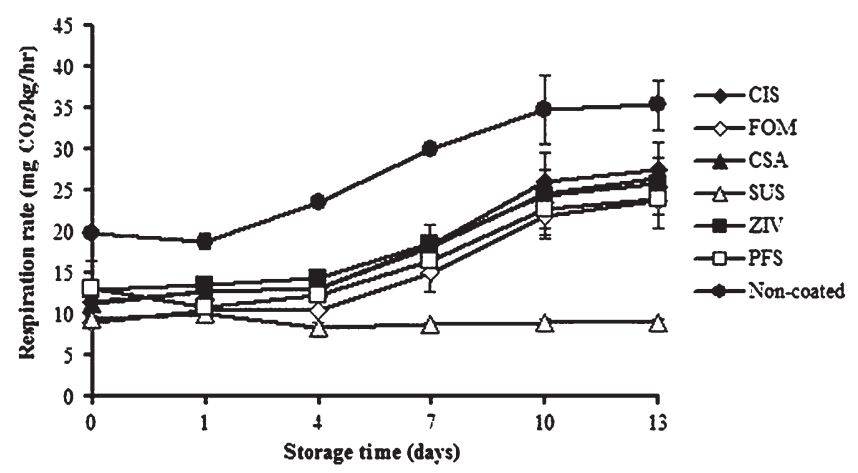

Fig. 6. Effects of commercial coatings on the respiration rate of tangerine fruit stored at room temperature $\left(23 \pm 3{ }^{\circ} \mathrm{C}\right)$ and $56 \% \pm 5 \%$ relative humidity for $13 \mathrm{~d}$. Mean separation by the least significant difference test at $P \leq 0.05$. treatment means \pm SD on Day 7 (Table 2) showed that \% TSS found in tangerine treated with Zivdar was higher than Citrashine, Fomesa, and untreated fruit. However, no significant difference of \%TSS was found in tangerine fruit coated with Citrosol AK, Supershine-C, or Perfect Shine coatings. Coated fruit showed less TSSs loss than control fruit and had also been reported for mandarin coated with different emulsions (Togrul and Arslan, 2004).

The $\mathrm{pH}$ value in fruit coated with Zivdar $(3.53 \pm 0.04)$ was higher than Citrashine (Table 2). There were no significant differences in $\mathrm{pH}$ between fruit treated with Zivdar, Fomesa, Citrosol AK, Supershine-C, and Perfect Shine coatings and the non-coated control. Comparison of treatment means showed an increasing trend of $\mathrm{pH}$ in all treatments during storage for $13 \mathrm{~d}$ (data not shown). The increase in $\mathrm{pH}$ may have been the result of the metabolisms of acids with respiration during storage (Togrul and Arslan, 2004).

Coating with Citrashine resulted in the highest \%TA $(0.59 \pm 0.04)$, whereas the lowest \%TA $(0.44 \% \pm 0.07 \%$ and $0.45 \% \pm$ $0.04 \%$ ) were observed in Zivdar- and Perfect Shine-coated fruit (Table 2). There was a decrease in acidity in all treatments during storage (data not shown). In this investigation, coating treatments did not affect loss of $\mathrm{TA}$ in tangerine fruit during storage.

The TSS/TA ratio of tangerine coated with Zivdar was higher than that of tangerines coated with Citrashine, Fomesa, Supershine$\mathrm{C}$, and non-coated control fruit (Table 2). Moreover, the results showed that the TSS/ TA ratio of all treatments was increased during storage (data not shown). Similar results were found in Aloe vera-coated cherry and starch-coated strawberry (Mali and Grossmann, 2003; Martinez-Romero et al., 2006).

The ascorbic acid content of coated tangerine fruit compared with non-coated control was not significantly different after $7 \mathrm{~d}$ of storage (Table 2). Ascorbic acid of yellow passion fruit coated with Fruit wax, Sparcitrus, Sunny Side Citrus, and polyethylene was not significantly different from control fruit (Mota et al., 2003).

\section{Conclusion}

Zivdar and Perfect Shine wax are best suited for coating 'Sai Nam Phueng' tangerine

Table 2. The quality attributes of 'Sai Nam Phueng' tangerine fruit stored at ambient temperature $\left(23 \pm 3{ }^{\circ} \mathrm{C}\right) 56 \% \pm 5 \%$ relative humidity for $7 \mathrm{~d}$ with wax treatments.

\begin{tabular}{lccccc}
\hline Treatments & TSS $(\%)$ & $\mathrm{pH}$ & TA $(\%)$ & TSS/TA & Vitamin C (mg/100 mL juice) \\
\hline CIS & $11.70 \pm 0.98^{\mathrm{b}}$ & $3.23 \pm 0.19^{\mathrm{b}}$ & $0.59 \pm 0.04^{\mathrm{a}}$ & $19.85 \pm 1.68^{\mathrm{b}}$ & $21.02 \pm 1.91$ \\
FOM & $11.37 \pm 0.60^{\mathrm{b}}$ & $3.36 \pm 0.02^{\mathrm{ab}}$ & $0.53 \pm 0.06^{\mathrm{ab}}$ & $21.86 \pm 3.91^{\mathrm{b}}$ & $21.66 \pm 1.10$ \\
CSA & $11.30 \pm 0.44^{\mathrm{bc}}$ & $3.45 \pm 0.17^{\mathrm{a}}$ & $0.48 \pm 0.10^{\mathrm{ab}}$ & $24.05 \pm 4.69^{\mathrm{ab}}$ & $20.38 \pm 2.21$ \\
SUS & $10.80 \pm 1.21^{\mathrm{bc}}$ & $3.39 \pm 0.10^{\mathrm{ab}}$ & $0.50 \pm 0.07^{\mathrm{ab}}$ & $21.89 \pm 3.53^{\mathrm{b}}$ & $21.66 \pm 1.10$ \\
ZIV & $12.17 \pm 1.00^{\mathrm{a}}$ & $3.53 \pm 0.04^{\mathrm{a}}$ & $0.44 \pm 0.07^{\mathrm{b}}$ & $28.45 \pm 6.00^{\mathrm{a}}$ & $2.94 \pm 1.70^{\mathrm{ab}}$ \\
PFS & $11.13 \pm 0.32^{\mathrm{bc}}$ & $3.45 \pm 0.01^{\mathrm{a}}$ & $0.45 \pm 0.04^{\mathrm{b}}$ & $24.94 \pm 1.10$ & $20.38 \pm 1.10$ \\
Non-coated & $9.90 \pm 0.70^{\mathrm{c}}$ & $3.49 \pm 0.08^{\mathrm{a}}$ & $0.48 \pm 0.06^{\mathrm{ab}}$ & $20.85 \pm 2.47^{\mathrm{b}}$ & $19.11 \pm 0.00$ \\
LSD $_{0.05}$ & 1.42 & 0.19 & 0.14 & 6.57 & 2.91 \\
\hline
\end{tabular}

Values are means \pm SD of three measurements. Mean separation within columns by the least significant difference test at $P \leq 0.05$.

Means followed by different superscript letters within a column are significantly different.

$\mathrm{TSS}=$ total soluble solids; TA $=$ titratable acidity; $\mathrm{LSD}=$ least significant difference. 
fruit because they had the least effects on modification of internal gas atmosphere, ethanol accumulation, and development of offflavor. All coatings reduced respiration rates and weight loss and provided higher gloss and better appearance than control fruit. Some coatings increased TSS levels but no major effects on $\mathrm{pH}, \mathrm{TA}$, and vitamin $\mathrm{C}$ contents.

\section{Literature Cited}

Ahmad, M. and I. Khan. 1987. Effect of waxing and cellophane lining on chemical quality indices of citrus fruit. Plant Foods Hum. Nutr. $37: 47-57$.

Aked, J. 2000. Fruits and vegetables, p. 249-278. In: Kilcast, D. and P. Subramaniam (eds.). The stability and shelf-life of food. CRC Press, Boca Raton, FL.

Amarante, C., N.H. Banks, and S. Ganesh. 2001 Relationship between character of skin cover of coated pears and permeance to water vapour and gases. Postharvest Biol. Technol. 21:291-301.

Bai, J., E.A. Baldwin, and R.H. Hagenmaier. 2002. Alternatives to shellac coatings provide comparable gloss, internal gas modification, and quality for delicious apple fruit. HortScience 37:559-563.

Baldwin, E.A., J.K. Burns, W. Kazokas, J.K Brecht, R.D. Hagenmaier, R.J. Bender, and E. Pesis. 1999. Effect of 2 edible coatings with different permeability characteristics on mango (Mangifera indica L.) ripening during storage. Postharvest Biol. Technol. 17:215-226.

Baldwin, E.A., M. Nisperos-Carriedo, P.E. Shaw, and J.K. Burns. 1995. Effect of coatings and prolonged storage conditions on fresh orange flavor volatiles, degrees Brix, and ascorbic acid levels. J. Agr. Food Chem. 43:1321-1331.

Banks, N.H. 1984. Some effects of TAL Pro-long coating on ripening bananas. J. Expt. Bot. 35: 127-137.

Ben-Yehoshua, S., S.P. Burg, and R. Young. 1985. Resistance of citrus fruit to mass transport of water vapor and other gases. Plant Physiol. 79:1048-1053.

Bonnichsen, R.K. and H. Theorell. 1951. An enzymatic method for the micro determination of ethanol. Scand. J. Clin. Lab. Invest. 3:58.

Chen, S. and A. Nussinovitch. 2000. Galactomannans in disturbances of structured waxhydrocolloid-based coatings of citrus fruit (easy-peelers). Food Hydrocoll. 14:561-568.

Chen, S. and A. Nussinovitch. 2001. Permeability and roughness determinations of wax-hydrocolloid coatings and their limitations in determining citrus fruit overall quality. Food Hydrocoll. 15:127-137.

Cohen, E., Y. Shalom, and I. Rosenberger. 1990. Postharvest ethanol build up and off-flavor in 'Murcott' tangerine fruits. J. Amer. Soc. Hort. Sci. 115:775-778

El Ghaouth, A., J. Arul, R. Ponnampalam, and M. Buolet. 1991. Chitosan coating effect on storability and quality of fresh strawberries. J. Food Sci. 56:1618-1620.

Hagenmaier, R.D. 1998. Selection of citrus 'wax' coatings on criteria other than short-term gloss. Packinghouse Newsletter. 182:1-4.

Hagenmaier, R.D. 2000. Evaluation of a polyethylenecandelilla coating for valencia oranges. Postharvest Biol. Technol. 19:147-154.

Hagenmaier, R.D. 2001. Ethanol content of 'Murcott' tangerines harvested at different times and treated with coatings of different $\mathrm{O}_{2}$ permeability. Proc. Flo. State Hort. Soc. 114:170 173.

Hagenmaier, R.D. 2002. The flavor of mandarin hybrids with different coatings. Postharvest Biol. Technol. 24:79-87.

Hagenmaier, R.D. 2005. A comparison of ethane, ethylene and $\mathrm{CO}_{2}$ peel permeance for fruit with different coatings. Postharvest Biol. Technol. 37:56-64.

Hagenmaier, R.D. and R.A. Baker. 1993. Reduction in gas exchange of citrus fruit by wax coatings. J. Agr. Food Chem. 41:283-287.

Hagenmaier, R.D. and R.A. Baker. 1994. Internal gases, ethanol content and gloss of citrus fruit coated with polyethylene wax, carnauba wax, shellac or resin at different application levels. Proc. Flo. State Hort. Soc. 107:261-265.

Hagenmaier, R.D. and R.A. Baker. 1995. Layered coatings to control weight loss and preserve gloss of citrus fruit. HortScience 30:296-298.

Hagenmaier, R.D. and P.E. Shaw. 1991. Permeability of shellac coatings to gases and water vapor. J. Agr. Food Chem. 39:825-829.

Hagenmaier, R.D. and P.E. Shaw. 1992. Gas permeability of fruit coating waxes. J. Amer. Soc. Hort. Sci. 117:105-109.

Jiang, Y. and Y. Li. 2001. Effects of chitosan coating on postharvest life and quality of longan fruit. Food Chem. 73:139-143.

Ke, D. and A.A. Kader. 1990. Tolerance of 'Valencia' oranges to controlled atmospheres as determined by physiological responses and quality attributes. J. Amer. Soc. Hort. Sci. 115: 770-783.

Lin, D. and Y. Zhao. 2007. Innovations in the development and application of edible coatings for fresh and minimally processed fruits and vegetables. CRFSFS 6:60-75.

Mali, S. and M.V.E. Grossmann. 2003. Effects of yam starch on storability and quality of fresh strawberries (Fragaria ananassa). J. Agr. Food Chem. 21:7005-7011.

Mannheim, C.H. and T. Soffer. 1996. Permeability of different coatings and their effect on citrus fruit quality. J. Agr. Food Chem. 44:919-923.

Martinez-Romero, D., N. Alburquerque, J.M. Valverde, F. Guillen, S. Castillo, D. Valero, and M. Serrano. 2006. Postharvest sweet cherry quality and safety maintenance by Aloe vera treatment: A new edible coating. Postharvest Biol. Technol. 39:93-100.

Matthesis, J.P., D.A. Buchanan, and J.K. Fellman. 1991. Changes in apple fruit volatiles after storage in atmospheres inducing anaerobic metabolism. J. Agr. Food Chem. 39:16021605 .

McHung, T.H. 1996. Effects of macromolecular interactions on the permeability of composite edible films, p. 234-244. In: Parris, N., A. Kato, L.K. Creamer, and J. Pearce (eds.). Macromolecular interactions in food technology. American Chemical Society, Washington, DC.

Mota, W.F., L.D.C. Shalomao, P.R. Cecon, and F.L. Finger. 2003. Waxes and plastic film in relation to the shelf life of yellow passion fruit. Sci. Agr. 60:51-57.

Nisperos-Carriedo, M.O., E. Shaw, and E.A. Baldwin. 1990. Changes in volatile flavor components of pineapple orange juice as influenced by application of lipid and composite films. J. Agr. Food Chem. 38:1382-1387.

Porat, R., B. Weiss, L. Cohen, A. Daus, and A Biton. 2005. Effects of polyethylene wax content and composition on taste, quality, and emission of off-flavor volatiles in 'Mor' mandarins. Postharvest Biol. Technol. 38:262268 .

Ranganna, S. 1986. Manual of analysis of fruit and vegetable products. Tata McGraw-Hill Publishing Company Limited, New Delhi, India.

Shaw, P.E., M.G. Moshonas, and E. Pesis. 1991. Changes during storage of oranges pretreated with nitrogen, carbon dioxide and acetaldehyde in air. J. Food Sci. 56:469-474.

Togrul, H. and N. Arslan. 2004. Carboxymethyl cellulose from sugar beet pulp cellulose as a hydrophilic polymer in coating of mandarin. J. Food Eng. 62:271-279.

Wills, R., B. McGlasson, D. Graham, and D. Joyce. 1998. Postharvest of fruit, vegetables, and ornamentals. 4th Ed. UNSW Press, Sydney, Australia. 